\title{
Blood Dosage of Vitamin D in Pregnant Women and Association with Preeclampsia and Fetal Low Weight
}

Dias $\mathrm{BA}^{1}$, Fraga CAC ${ }^{1}$, de Rezende Goston $\mathrm{HSR}^{1}$, Guerra $\mathrm{PB}^{1}$, Heringer VCCR ${ }^{1}$, Rodrigues $\mathrm{YS}^{1}$, Panconi $\mathrm{CR}^{2}$, Coutinho $\mathrm{LM}^{2}$, de Souza $\mathrm{HD}^{2}$, Batalha $\mathrm{SH}^{2}$, Silva $\mathrm{CS}^{2}$, Zimmermmann $\mathrm{JB}^{1,2^{*}}$

${ }^{1}$ Barbacena Faculty of Medicine

${ }^{2}$ Federal University of Juiz de Fora

Corresponding Author: Prof. Juliana Barroso Zimmermmann

Address: Juiz de Fora - MG, Federal University of Juiz de Fora, Materno-Infantil Department; E-mail: julianabz@uol.com.br

Received date: 10 December 2019; Accepted date: 14 February 2020; Published date: 21 February 2020

Citation: Dias BA, Fraga CAC, de Rezende Goston HSR, Guerra PB, Heringer VCCR, Rodrigues YS, Panconi CR, Coutinho LM, de Souza HD, Batalha SH, Silva CS, Zimmermmann JB. Blood Dosage of Vitamin D in Pregnant Women and Association with Preeclampsia and Fetal Low Weight. Asp Biomed Clin Case Rep. 2020 Feb 21;3(1):51-61.

Copyright (C) 2020 Dias BA, Fraga CAC, de Rezende Goston HSR, Guerra PB, Heringer VCCR, Rodrigues YS, Panconi CR, Coutinho LM, de Souza HD, Batalha SH, Silva CS, Zimmermmann JB. This is an open-access article distributed under the Creative Commons Attribution License, which permits unrestricted use, distribution, and reproduction in any medium provided the original work is properly cited.

\section{Abstract}

Objective: The present study aimed to evaluate the vitamin D blood dosage during the three gestational trimesters, while identifying the frequency of pregnant women in the normal range, the variance in the three periods and evaluate the association between vitamin $\mathrm{D}$ and the obstetric complications such as preeclampsia, diabetes, and weight of the newborn.

Methods: This is a longitudinal study with pregnant and non-pregnant women, from which there was collected data of anamneses, physical exam, obstetric info, as well as milk consumption habits, sunscreen and sun exposure, and also the vitamin D blood dosage.

Results: There were 91 Pregnant Women studied, from whom the comparison between the vitamin D dosages identified the absence of gestation as a protective factor for VDD; the tendency for lower levels of supplementations when the workplace is in an external environment; the association between vitamin D and preeclampsia in the first trimester.

Conclusion: The most relevant consequences from VDD were pre-eclampsia in the first trimester, the absence of gestation as a protective factor for VDD, and the need to consider the workplace before supplementation.

\section{Keywords}

Prenatal Care; Vitamin D; Pre-eclampsia

\section{Introduction}

The vitamin D or $25(\mathrm{OH}) \mathrm{D}$ is involved in the work mechanics of the musculoskeletal system, in regulating the calcium, phosphor, parathyroid hormone (PTH) and calcitonin (thyroid) metabolism. It is known that vitamin $\mathrm{D}$ is a necessary factor for the growth and maintenance of the bone tissue and the maintenance of the calcium and phosphor homeostasis. Furthermore, studies have proven the involvement of this vitamin in many cellular processes, including on differentiation and proliferation effects, hormonal secretions, immune 
Citation: Dias BA, Fraga CAC, de Rezende Goston HSR, Guerra PB, Heringer VCCR, Rodrigues YS, Panconi CR, Coutinho LM, de Souza HD, Batalha SH, Silva CS, Zimmermmann JB. Blood Dosage of Vitamin D in Pregnant Women and Association with Preeclampsia and Fetal Low Weight. Asp Biomed Clin Case Rep. 2020 Feb 21;3(1):51-61.

Original Article

system and in some non-transmissible chronic ilnesses [1].

There are two vitamin D sources, one exogenous throw the diet in the form of vitamin D2 (calciferol) and D3 (cholecalciferol) and the other by the endogenous production. Throw the endogenous, the D3 (cholecalciferol), the main vitamin D source is synthesized in the skin by the ultraviolet radiation $\mathrm{B}$ (UVB) action by the photolyses of the 7dehydrocholesterol transforming in vitamin D3 [2-4].

The main source of vitamin D for children as well as for adults is sunlight exposure, therefore the main VDD cause is the endogenous decreased production. Any factor that interferes in the UVB ration transmission or interferes with its skin penetration will determine a decrease of $25(\mathrm{OH}) \mathrm{D}$. That is why dark-skinned persons have natural protection against the sun, because of the melanin absorbers the UVB radiation, being necessary a solar exposure 3 to 5 times longer to synthesize the same amount of vitamin $\mathrm{D}$ as the light-skinned person. The use of sunblocks with sun protective factor 30 downsizes the skin vitamin D synthesis above 95\%. Also, the natural skin aging and age decrease the cutaneous vitamin $\mathrm{D}$ production capability, because of the lesser 7dehydrocholesterol availability and skin damages such as burns also decreases vitamin $\mathrm{D}$ production. The atmospheric contamination and the cloudiness can act as a sunblock, as well as the year station and the time of the day influence the vitamin $\mathrm{D}$ cutaneous production $[5,6]$.

Throughout gestation and lactation, significant changes in the calcium and vitamin D metabolism occur to provide for the fetus bone mineralization needs. In the first trimester, the fetus accumulates 2-3 $\mathrm{mg} /$ day of calcium in the skeleton, which doubles in the last trimester. The pregnant woman adapts to the fetus needs and increases the calcium absorption at the beginning of the pregnancy, reaching the maximum level in the last trimester, it happens with the increase of intestinal absorption e decrease of urinary excretion. Beyond that, the $1,25(\mathrm{OH}) \mathrm{D}$ plasma levels increase at the beginning of pregnancy, also reaching the maximum level in the third trimester, and returning to normal during lactation [5]. The reason for the increase in syntheses of $1,25(\mathrm{OH}) \mathrm{D}$ is still unknown, being that the PTH levels do not change during gestation.

It is believed that fetal PTH is responsible for the increase of vitamin D during pregnancy since when reaching the maternal circulation, it takes part in the calcium and the PTH level regulation processes in pregnant. The prolactin and the lactogenic placentary hormone also increase the intestinal calcium absorption, decrease its urinary excretion and promote the fetal parathormone (PTHrP) and the calcitriol or $1,25(\mathrm{OH}) 2 \mathrm{D}$ production. During the lactation, there is a relative estrogen deficiency due to the prolactin level increase, which determines the bone reabsorption and PTH levels suppression. The PTHrP levels are increased and act as a substitute for PTH, maintaining the urinary calcium absorption and bone reabsorption $[1,5]$.

During pregnancy, the decrease of vitamin D has been associated with pre-eclampsia, insulin resistance, gestational diabetes, bacterial vaginosis and an increase in cesarean delivery. It is believed that vitamin D supplementation reduces pre-eclampsia risk [5]. Studies with pre-eclampsia women have demonstrated low calcium urinary excretion, low ionized calcium levels, high PTH levels and low 1,25(OH)2D levels [5].

Taking a base on what was here exposed, it can be assumed that pregnant can have lower vitamin D levels than non-pregnant adult women as there is a bigger need for calcium absorption for the fetus. Whereas there still isn't a vitamin D dosage level consensus, we propose evaluating this dosage in the different trimesters of pregnancy and its association with clinical and epidemiological data.

\section{Objectives}

- To evaluate the vitamin D level in the threepregnancy trimester to identify the variation during the three trimesters;

- To evaluate the association between vitamin D 
Citation: Dias BA, Fraga CAC, de Rezende Goston HSR, Guerra PB, Heringer VCCR, Rodrigues YS, Panconi CR, Coutinho LM, de Souza HD, Batalha SH, Silva CS, Zimmermmann JB. Blood Dosage of Vitamin D in Pregnant Women and Association with Preeclampsia and Fetal Low Weight. Asp Biomed Clin Case Rep. 2020 Feb 21;3(1):51-61.

Original Article

level and obstetric complications (preeclampsia and weight of birth).

\section{Patients and Methods}

Patients:

1) Type of Study

This is a longitudinal study with 91 pregnant women accompanied by the low-risk service of the Medicine College of Barbacena and Federal University from Juiz de Fora.

The pregnant were submitted to vitamin D level in the three trimesters. The comparison of pregnant from the different institutions was possible due to the usage of the FEBRASGO (Brazilian Federation of Gynecology and Obstetrics) [7] protocol for clinic attendance and these locations where considered prenatal suitable in a previous study [8]. Furthermore, the team responsible for the attendance had the same coordinator, which facilitated the homogeneity of the protocols.

All the data of anamneses, physical exam, obstetric info (preeclampsia, gestation diabetes, fetal loss, fetal obit, the weight of birth) as well as milk consumption habits, sunscreen and sun exposure, and also the vitamin D blood levels were collected. The same data was collected from non-pregnant women. Beyond that, all the women were submitted to vitamin D blood level measurement.

In this study, the women were included who are agreed to take part in the protoal and excluded the ones that didn't agree with the protocol or the services. Considering the risk factor, the vitamin D blood level measurement is a relatively common exam that took part with the pregnancy usual propaedeutic. As a primary development it was considered the hypovitaminosis $\mathrm{D}$ (dosages below $30 \mathrm{ng} / \mathrm{mL}$ ) and as a secondary development the pre-eclampsia, low weight of birth and gestation diabetes. All the women that agreed in taking part in the study signed an informed consent form (TCLE).

\section{Methods}

Clinical Methods:
The solar exposure evaluation was divided in usual exposure - characterized by the day to day usual activities while walking on the streets - the extra exposure - characterized by the beach or swimming pool exposure in the last 6 months.

The sunscreen evaluation was considered as YES for those who routinely made use on any body part exposed to the sun; NO for those who didn't routinely or commonly use sunscreen; and VARIABLE for those who used sunscreen only on special occasions.

The milk and dairy consumption evaluations were considered in this study as NO for those who didn't consume milk or consumed less than once a week. As YES included, those that consumed milk or dairy as the following method: low - once or twice a week; regular - twice to three times a week; good - those who consumed more than 3 times a week. The consumption during meals wasn't taking into account.

\section{Laboratorial Methods:}

1) Vitamin D Blood Level and the Normality Level Used in the Study

The vitamin $\mathrm{D}$ dosage was solicited for the pregnant in all the trimesters. The method used for the vitamin D dosage was Elecsys Vitamin D (electrochemiluminescence). This method was approved by the FDA in 2012. In 2017, The Brazilian Society of Clinical Pathology / Laboratory Medicine (SBPC/ML) announced a change in the reference value for vitamin D dosage, being so that in this study was used the new proposal.

This way, based on this classification above described by SBPC/ML [9] this study was adopted in the following way:

A. Elevated: $>100 \mathrm{ng} / \mathrm{mL}$ is considered elevated with hyperkalemia risk;

B. Normal: $>20 \mathrm{ng} / \mathrm{mL}$ is desirable for the general healthy population;

C. Normal for risk groups: in between 30 and 60 $\mathrm{ng} / \mathrm{mL}$ is the recommended for the risk groups such as elderly, pregnant, osteoporosis, secondary hyperparathyroidism, inflammatory 
Citation: Dias BA, Fraga CAC, de Rezende Goston HSR, Guerra PB, Heringer VCCR, Rodrigues YS, Panconi CR, Coutinho LM, de Souza HD, Batalha SH, Silva CS, Zimmermmann JB. Blood Dosage of Vitamin D in Pregnant Women and Association with Preeclampsia and Fetal Low Weight. Asp Biomed Clin Case Rep. 2020 Feb 21;3(1):51-61.

Original Article

diseases, autoimmune diseases, and chronic kidney diseases;

D. Low: in between 10 and $20 \mathrm{ng} / \mathrm{mL}$ is considered low, with an elevated bone remodeling risk and, with that, loss in bone mass, as well as osteoporosis and fracture risk;

E. Very low: <10 ng/mL, having bone mineralization defect risk.

2) Considerations as for the Newborn Weight:

It was considered low birth weight, those newborns with less than $2500 \mathrm{~g}$ in birth from 37 weeks.

\section{3) Statistics Methods:}

The collected data was digitized directly on an excel spreadsheet and afterward exported to the Epi Info vs 6.o. There compared vitamin D dosage levels in each trimester and its association with the clinical and epidemiological data. The statistics test utilized where the variable analyses (ANOVA) for an average between groups comparison or the square-qui test for categorical variable or, when necessary, the Kruskal Wallis test ( $\mathrm{H}$ test). The significance level was $\mathrm{p}<0,05$.

4) Ethical Considerations:

The present study was approved by the ethical and research committee from the Medicine College of Barbacena, the number was 2.352.710 and CAAE 76102517.4.1001.5119.

\section{Results}

There were 91 pregnant women. In the matter of color, the patients were classified as white or nonwhite based on a self-proclaimed statement, therefore, the average $\mathrm{D}$ vitamin level by the patients who considered themselves white was 29,21 \pm 13,22 ( $\mathrm{n}=99)$ and by the patients who considered themselves nonwhite was $34,04 \pm 19,14(n=45)$, with a $\mathrm{p}=0,08 ; \mathrm{F}=3,08$. The epidemiological and clinical aspects of the studied patients are exposed in (Table-1).

The average vitamin $d$ level including all of the patients was $30,72 \pm 15,41 \mathrm{ng} / \mathrm{mL}$, with a minimum of 9 and a maximum of $118 \mathrm{ng} / \mathrm{mL}$.

There was no association D vitamin level and age $(\mathrm{p}=\mathrm{o}, 3)$, number of pregnancies $(\mathrm{p}=0,4)$, number of childbirths $(p=0,2)$ and number of abortions $(p=0,14)$, skin color $(p=0,08)$. In the matter of the obstetric aspects there wasn't identified a connection between vitamin $\mathrm{D}$ and pre-natal weight gain $(\mathrm{p}=\mathrm{o}, 49)$,

\begin{tabular}{|c|c|c|}
\hline \multicolumn{3}{|c|}{ Table-1: Epidemiological and Clinical Aspects of the Studied Patients } \\
\hline Evaluated Data & \multicolumn{2}{|c|}{ Media } \\
\hline Age (years) & \multicolumn{2}{|c|}{$32,2 \pm 5,7$} \\
\hline Pregnancies & \multicolumn{2}{|c|}{$1,70 \pm 1,3$} \\
\hline Parity & \multicolumn{2}{|c|}{$0,46 \pm 0,6$} \\
\hline Abortions & \multicolumn{2}{|c|}{$0,27 \pm 0,7$} \\
\hline Gestational Age in the pre-natal beginning (weeks) & \multicolumn{2}{|c|}{$10,55 \pm 5,8$} \\
\hline Gestational Age in the pre-natal ending (weeks) & \multicolumn{2}{|c|}{$37,54 \pm 4,31$} \\
\hline Diastolic arterial pressure in the pre-natal beginning $(\mathrm{mmHg})$ & \multicolumn{2}{|c|}{$75,3 \pm 12,4$} \\
\hline Diastolic arterial pressure in the pre-natal ending $(\mathrm{mmHg})$ & \multicolumn{2}{|c|}{$81,0 \pm 11,5$} \\
\hline Systolic arterial pressure in the pre-natal beginning $(\mathrm{mmHg})$ & \multicolumn{2}{|c|}{$116,0 \pm 15,22$} \\
\hline Systolic arterial pressure in the pre-natal ending $(\mathrm{mmHg})$ & \multicolumn{2}{|c|}{$122,85 \pm 16,7$} \\
\hline Weight gain $(\mathrm{Kg})$ & \multicolumn{2}{|c|}{$7,7 \pm 5,6$} \\
\hline Ilness & $\mathrm{N}$ & $\%$ \\
\hline Diabetes & 4 & 4,65 \\
\hline Chronical Hypertension & 15 & 17,4 \\
\hline Thyroid illnesses & 7 & 7,6 \\
\hline
\end{tabular}


Citation: Dias BA, Fraga CAC, de Rezende Goston HSR, Guerra PB, Heringer VCCR, Rodrigues YS, Panconi CR, Coutinho LM, de Souza HD, Batalha SH, Silva CS, Zimmermmann JB. Blood Dosage of Vitamin D in Pregnant Women and Association with Preeclampsia and Fetal Low Weight. Asp Biomed Clin Case Rep. 2020 Feb 21;3(1):51-61.

\section{Original Article}

chronical arterial hypertension $(\mathrm{p}=\mathrm{o}, 88)$, thyroid illnesses $(p=0,40)$ or diabetes $(p=0,95)$.

The vitamin D level took place in all the trimesters. The average during the first trimester was 30,07 \pm $18,12 \mathrm{ng} / \mathrm{mL}$; during the second was $50,51 \pm 41,47$ $\mathrm{ng} / \mathrm{mL}$ and during the third was 43,63 $\pm 28,59 \mathrm{ng} / \mathrm{mL}$ as follows in (Table-2).

The vitamin D level was evaluated as the classification described in the methodology. There was identified a normal level (53,90\%), low (39,61\%), high $(3,9 \%)$, very low (1,95\%) every high (0,65\%) during the first pregnancy trimester.

During the second trimester, the normal level was identified in $56,45 \%$, low in $25,81 \%$, very high in $9,68 \%$ and high in 8,o6\%. In this period there wasn't identified a very low dosage and vitamin D deficiency was present in $25,81 \%$ of the cases. In the third trimester, the normal vitamin $\mathrm{D}$ blood dosage level was identified in $71,74 \%$, low in $19,57 \%$, very high in $6,52 \%$ and high in $2,17 \%$ of the cases.

Considering the treatment, there was a significant vitamin D deficiency reduction on the second and third pregnancy trimesters and the prescription was made for those that had the lowest blood dosage level $(\mathrm{p}<0,05)$. From the studied women, 3 pregnants had used D vitamin prior to the first appointment $(3,33 \%)$. However, after the first obstetric or gynecological evaluation, there was identified that 64 pregnant $(71,11 \%)$ had used D vitamin. The women with a very high level, where orientate the suspension of the supplementation, with reevaluation in 30 days.

During the first trimester, among the nonsupplemented pregnant the vitamin $\mathrm{D}$ level average was $41,83 \pm 27,00 \mathrm{ng} / \mathrm{mL}$ and those that have initiated the supplementation were $26.49 \pm 12,80$

Table-2: Vitamin D dosage level in pregnant women in the three trimesters. Values in $\mathrm{ng} / \mathrm{mL}$.

\begin{tabular}{|c|c|c|c|}
\hline Vitamin D & First Trimester & Second Trimester & Third Trimester \\
\hline Pregnant & $30,07 \pm 18,12$ & $50,51 \pm 41,47$ & $43,63 \pm 28,59$ \\
\hline
\end{tabular}

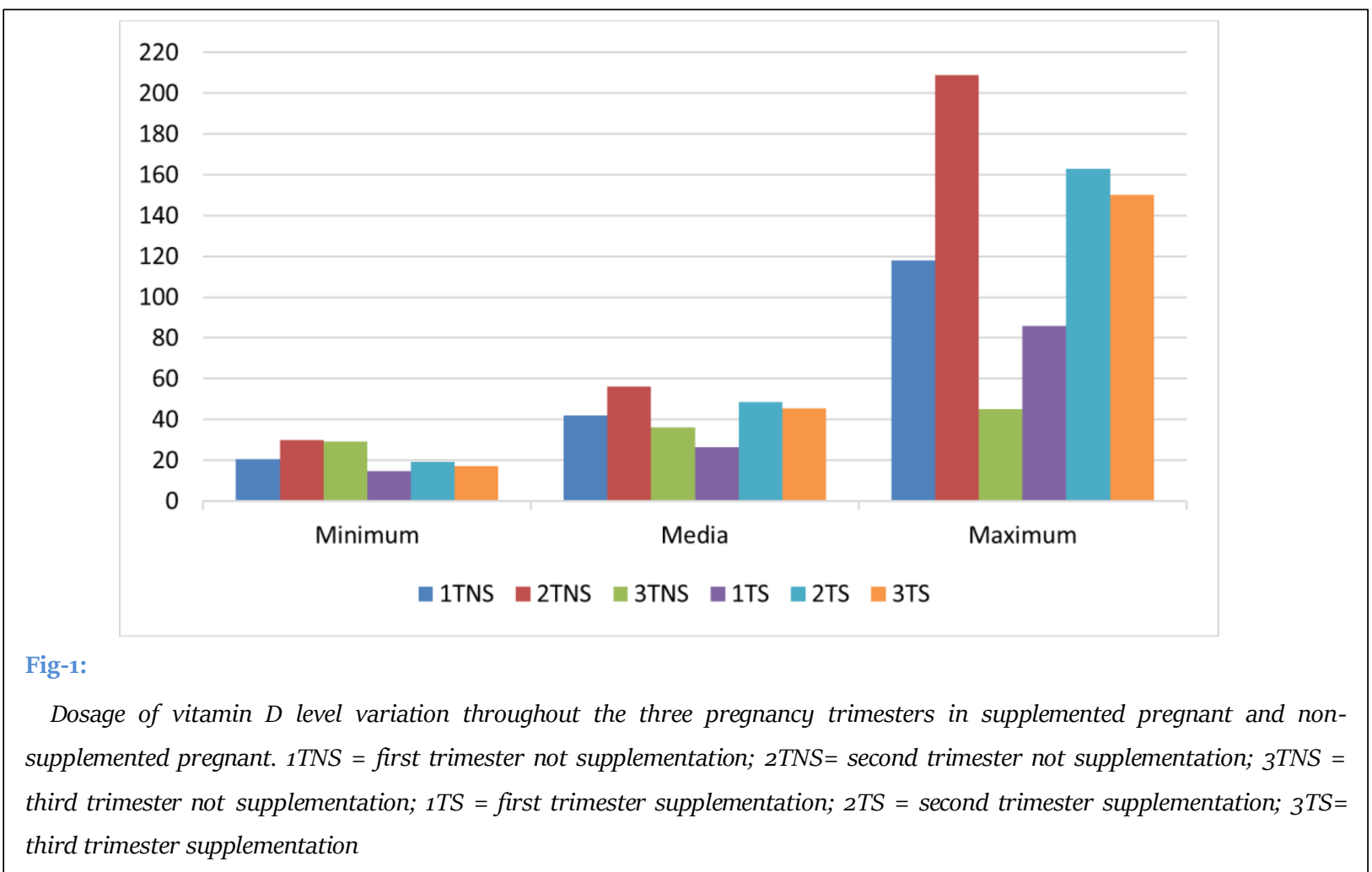


Citation: Dias BA, Fraga CAC, de Rezende Goston HSR, Guerra PB, Heringer VCCR, Rodrigues YS, Panconi CR, Coutinho LM, de Souza HD, Batalha SH, Silva CS, Zimmermmann JB. Blood Dosage of Vitamin D in Pregnant Women and Association with Preeclampsia and Fetal Low Weight. Asp Biomed Clin Case Rep. 2020 Feb 21;3(1):51-61.

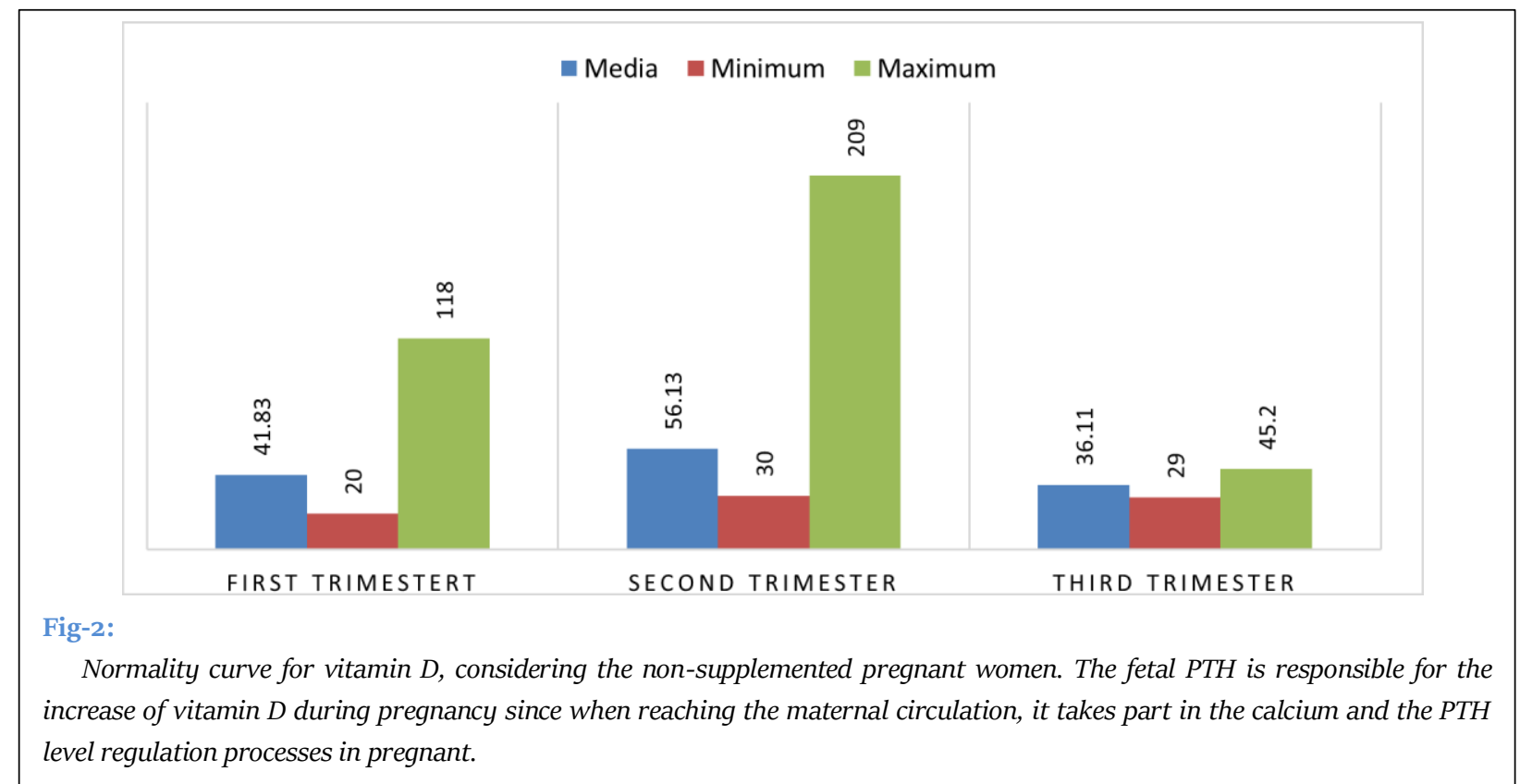

$\mathrm{ng} / \mathrm{mL}$. During the second trimester, those who didn't keep the supplementation had an average of $56,13 \pm$ $49,85 \mathrm{ng} / \mathrm{mL}$ and among those that started or kept the supplementation had of $48,36 \pm 38,42 \mathrm{ng} / \mathrm{mL}$. Finally, during the third trimester the average of the nonsupplemented was $36,11 \pm 5,74 \mathrm{ng} / \mathrm{mL}$ and among the supplemented was $45,58 \pm 31,76 \mathrm{ng} / \mathrm{mL}$ (Fig-1 and Fig-2).

There was also made the association between sunlight exposure and the usage of sunscreen and the self-proclaimed skin color, not having a connection for sunlight exposure $\left(\mathrm{p}=0,2: \mathrm{X}^{2}=2,4\right)$ or sunscreen usage $\left(p=0,5 ; X^{2}=1,1\right)$. The external environment of the workplace showed a lower vitamin D supplementation prescription tendency $(\mathrm{p}=\mathrm{o}, \mathrm{0} 5)$.

There was an association between low vitamin D levels during the first trimester and pre-eclampsia $(\mathrm{p}=0,004)$, but there wasn't during the second and third trimesters $(p>0,05)$. Interesting data is that, although the higher vitamin $\mathrm{D}$ level had been connected with pre-eclampsia, our results identified that the pregnant that were supplemented during the first trimester, where those that have the smaller chances of pre-eclampsia ( $\mathrm{p}=0,009 ; \mathrm{OR}=0,09$; IC=0,01-0,81). Though, the spotting of a patient with extremely high levels deviated superiorly the average and, that is why the results were conflicting. The exclusion of this patient allowed us to identify that the

Table-3: Association between Vitamin D Dosage Level with Pre-eclampsia. Values in ng/mL.

\begin{tabular}{|l|c|c|c|c|}
\hline \multicolumn{5}{|c|}{ Preeclampsia } \\
\hline & Vitamin D first trimester & Vitamin D second trimester & Vitamin D third trimester \\
\hline Yes & $58,46 \pm 51,62$ & $52,57 \pm 43,0$ & $38,05 \pm 7,14$ \\
\hline No & $28,57 \pm 14,33$ & $50,32 \pm 21,55$ & $43,94 \pm 29,32$ \\
\hline P value & 0,00443 & 0,91 & \multicolumn{2}{|c|}{0,78} \\
\hline Vitamin D supplemented & \multicolumn{3}{|c|}{$\mathrm{p}$} & $\mathrm{X}^{2}$ \\
\hline \multicolumn{5}{|c|}{ Preeclampsia } \\
\hline
\end{tabular}


Citation: Dias BA, Fraga CAC, de Rezende Goston HSR, Guerra PB, Heringer VCCR, Rodrigues YS, Panconi CR, Coutinho LM, de Souza HD, Batalha SH, Silva CS, Zimmermmann JB. Blood Dosage of Vitamin D in Pregnant Women and Association with Preeclampsia and Fetal Low Weight. Asp Biomed Clin Case Rep. 2020 Feb 21;3(1):51-61.

Original Article

low vitamin D level in the first trimester was indeed associated with pre-eclampsia $(\mathrm{p}=0,03)$.

The average birth weight was 3250 . There was no association between vitamin $\mathrm{D}$ level during the first $\left(\mathrm{p}=0,5^{2}\right)$, second $(\mathrm{p}=0,54)$ and third trimesters $(\mathrm{p}=0,20)$ and newborn weight (Table-3).

\section{Discussion}

Hypovitaminosis D was observed as frequent in this population. Such results are compatible with the literature that states that VDD during pregnancy is a worldwide epidemic with studies showing prevalence between $18-84 \%$ depending on the country, residency, local and population garments [10]. In our study, vitamin D deficiency was $41,56 \%$, compatible with the described in the literature, and, therefore, there is a worldwide consumption with this hypovitaminosis during pregnancy and its influence on the maternal and fetal outcome [11].

The lack of pregnancy was a protective factor for VDD, during the first trimester. Some authors believe that the vitamin D dosage level downsizing during the first trimester is associated with the fetal skeleton formation. Therefore, the fetal parathyroid hormone would be responsible to determine the motherly bone reabsorption and optimize the mother calcium blood levels for the fetal skeleton under construction [1-5]. Studies have shown that women with vitamin D dosage levels lower than $30 \mu \mathrm{mol} / \mathrm{mL}$ had children with lighter newborn weight and smaller cephalic perimeter and a greater small for gestational age infants (SGA) risk in comparison with mothers with concentrations $\geq 30 \mu \mathrm{mol} / \mathrm{mL}$ [12]. In our study the newborn weight didn't show variation connecting to the vitamin D dosage level, being so that this could have been due to an early beginning of supplementation.

When the vitamin D dosage level was evaluated during the pregnancy trimesters, it showed an increment of its blood dosage, in a way that the supplementation was considered efficient, lowering its deficit. Although it wasn't the study's objective, the majority of the patients used a weekly average dosage of 7000 UI [13].
There was an association between sunlight exposure and vitamin D dosage level, being so that the blood dosage level was found more elevated as bigger the sunlight exposure was. A study done in Canada [14] identified that European ancestry and collecting blood samples during summer were significantly associated with a higher $25(\mathrm{OH}) \mathrm{D}$ concentration in the maternal blood. These authors concluded that vitamin D status is enough in most of the European ancestry Canadian women, probably due to sunlight exposure. It's curious that, although we live in a tropical country, our results demonstrated vitamin D dosage levels averages a lot lower than the studies that took place in other countries. For example, in Canada the vitamin D blood level was $70 \mu \mathrm{mol} / \mathrm{mL}$, a lot higher than the Brazilian average mentioned in different studies. In this study, the general average was 30 $\mu \mathrm{mol} / \mathrm{mL}$, compatible with other researches that took place in different Brazilian cities. Prado et al [15], identified a VDD in 61 (27\%) women and in 66 $(29,2 \%)$ of their newborns, 131 (58\%) women and 116 $(51,3 \%)$ newborn presented with vitamin D insufficiency and only 34 (15\%) women and 44 $(19,5 \%)$ newborn presented enough vitamin D. The severe VDD (VD levels $\leq 10 \mathrm{ng} / \mathrm{mL}$ ) was observed in 15 $(11,9 \%)$ women and in $4(1,8 \%)$ newborn.

These authors considered VDD as lower than 20 $\mu \mathrm{mol} / \mathrm{mL}$ and insufficiency when the values were between 20 and $30 \mu \mathrm{mol} / \mathrm{mL}$. Furthermore, it was verified that the sunscreen usage and working in an internal environment determined lower vitamin D dosage levels, though not statistically significant, but with clinical relevance. Some studies have demonstrated that the daily sunscreen usage hasn't proven to be a vitamin D insufficiency cause, is that the quantity, the appliance of the product and the protective factor are elements that need to be considered and are variables that are hard to control. Recently a study published in Up to Date [16] concluded that there is no evidence in randomized studies or longitudinal studies in real-life canaries in which the usage of sunscreen significantly suppresses the cutaneous vitamin D production. On the other hand, in an experimental environment, vitamin D production seems to be greatly reduced by the 
Citation: Dias BA, Fraga CAC, de Rezende Goston HSR, Guerra PB, Heringer VCCR, Rodrigues YS, Panconi CR, Coutinho LM, de Souza HD, Batalha SH, Silva CS, Zimmermmann JB. Blood Dosage of Vitamin D in Pregnant Women and Association with Preeclampsia and Fetal Low Weight. Asp Biomed Clin Case Rep. 2020 Feb 21;3(1):51-61.

Original Article

adequate amount of sunscreen applied before the ultraviolet light exposure [16].

It is believed that the sunlight exposure is the most important element in the vitamin D blood dosage level, but surely it isn't the only one, because this single exposure doesn't explain the different vitamin D dosage level observed in different countries, especially the tropical ones. It is important to note that this study has limitations on sun exposure and the use of sunscreen since these elements were considered only by the self-declaration of patients.

The milk and dairy consumption were evaluated as stated in methodology and there wasn't observed any differences, maybe because as we stratified in many subgroups, it was prejudicial for the evaluation of the statistics. However, when we suppressed the subgroups and evaluated two groups (good consumption and no consumption), we identified statistic relevance in all groups, being so that the good consumption of milk and dairy products can increase the vitamin D dosage level [17-19].

The vitamin D level was lower within the pregnant women, this emphasizes that being pregnant and building a new skeleton - the fetus - is a risk factor for low vitamin D levels. Mulligan et al, [11] describe that the current prenatal doesn't include the vitamin D level monitoring, which is an unhappy flaw because its deficiency is easily treated. On average, vitamin D dietary supplements of 1000-200o UI that cost U\$1-2 per month in the USA. According to these authors, women with more than one vitamin $\mathrm{D}$ deficiency risk factor (dark skin, living in cold countries, low sunlight exposure, obese, with habits of covering all of their body parts with clothes, who regularly use sunscreen) should have a $25(\mathrm{OH}) \mathrm{D}$ plasmatic level traced in the beginning and half of the pregnancy.

In the USA, the current vitamin D intake during pregnancy recommendation is 200 a $400 \mathrm{UI} /$ day. However, other studies $[20,21]$ have shown that prenatal supplements containing 400 UI of vitamin D are not sufficient to achieve normal vitamin D levels in pregnant and their babies. Furthermore and more alarming, studies with $800-1600$ UI of vitamin D per day during the last pregnancy trimester in women with $25(\mathrm{OH}) \mathrm{D}<15 \mathrm{ng} / \mathrm{mL}$ levels have shown that the vitamin $\mathrm{D}$ dosage levels raised from $5,8 \mathrm{ng} / \mathrm{mL}$ to 11 $\mathrm{ng} / \mathrm{mL}$ [20-22]. Thus, vitamin $\mathrm{D}$ supplements in a dosage that exceeds 1000 IU per day (2000-10.000 $\mathrm{UI} / \mathrm{d}$ ) can be necessary to achieve a normal blood vitamin D in grave vitamin D deficiency patients. Daily

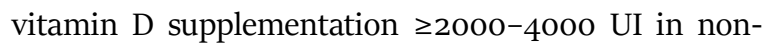
pregnant women have shown secure and effective in achieving normal vitamin D level [23]. Our results are compatible with the mentioned in the literature because with a 7000 UI dosage we have achieved vitamin D blood levels increments, but 19,57\% were still considered with low dosage levels, which suggests that these patients may need higher dosages [20-23].

When we associated the vitamin D dosage level and pre-eclampsia, we verified that pregnant with elevated dosage levels in the first trimester had greater preeclampsia risk. It is curious that there was protection when using vitamin D supplementation. With this apparently controversial data, we identified one patient, with previous vitamin $\mathrm{D}$ intake, that deviated the average upwards. The exclusion of this patient forms data analytics allowed the correction of this initial interpretation. Therefore, it was ascertained that first-trimester hypovitaminosis $\mathrm{D}$ was indeed a risk factor for pre-eclampsia $(\mathrm{p}<0,05)$, maybe because the pre-eclampsia is a disease that has inappropriate placentation in its geneses. Being so, the bad placentation, the endothelial damage, and the oxidative mediator release determine vasoconstriction and the clinical illness manifestation as a consequence. For this reason, the low dosage of vitamin $\mathrm{D}$ in early pregnancy can damage the placenta, determining preeclampsia. The same did not happen with vitamin D levels in the second and third trimesters. We believe that placentation occurring up to 16 weeks (trophoblastic migration), vitamin D levels after this period would be of little importance for the formation of the placenta.

A study made in 2018 [24], verified that autophagy is involved in the trophoblast survivor capability. As vitamin $\mathrm{D}$ has a central role in many cellular processes, it is possible that it can influence the trophoblast's vital capability. The mother's vitamin D 
Citation: Dias BA, Fraga CAC, de Rezende Goston HSR, Guerra PB, Heringer VCCR, Rodrigues YS, Panconi CR, Coutinho LM, de Souza HD, Batalha SH, Silva CS, Zimmermmann JB. Blood Dosage of Vitamin D in Pregnant Women and Association with Preeclampsia and Fetal Low Weight. Asp Biomed Clin Case Rep. 2020 Feb 21;3(1):51-61.

Original Article

deficiency was found in every pathological pregnancy with combined low vitamin $\mathrm{D}$ placental receptors levels (VDR) in intrauterine growth restriction. According to Talfield [25] et al, vitamin D supplementation reduces the preeclampsia risk. Studies in women with preeclampsia have shown low calcium urinary excretion, low ionized calcium levels, high PTH levels, and low 1,25(OH)2D levels. These results corroborate our findings that vitamin D supplementation reduces the pre-eclampsia chance in pregnant. A study made in Est Iran identified that preeclampsia women $(n=80)$ had lower levels of $25(\mathrm{OH}) \mathrm{D}$ when compared to healthy control women $(\mathrm{n}=80 ; \mathrm{p}=0,01)$. This total difference of $25(\mathrm{OH}) \mathrm{D}$ remained significant even after the probable confounders were controlled $(\mathrm{OR})=4,79$, confidence interval $(\mathrm{CI})=1,45-9,87, \mathrm{p}=0,01$ [26].

It is common knowledge that hypovitaminosis D is a public health service problem. In pregnant, it determines complications with motherly and fetal adverse outcomes. In Brazil, many stuidies [8,9,19,20] have pointed out the vitamin $\mathrm{D}$ deficit in our population and it would be a clever strategy the vitamin $\mathrm{D}$ blood screening during pregnancy. The sunlight exposure was an important element in the vitamin D blood level, as well as milk and dairy products consumption when compared with patients that didn't consume these products. The preeclampsia was associated with the low blood level in the first trimester and its replacement was considered a protective factor. The 7000 UI dosage was capable of reducing the hypovitaminosis $\mathrm{D}$, but it wasn't able to extinguish it completely, what is suggestive that pregnant may need higher dosages than $7000 \mathrm{UI}$, especially within those with lower dosages levels during the first pregnancy trimester.

Albeit some limitations, such as the non-evaluation of the sunscreen factor, the body mass index (BMI), is that we evaluated only the pregnant weight gain, the skin color is made by self-proclamation, and not having studied the supplementation dosage, our data is important because it identifies the vitamin D deficit in a large percentage of the studied pregnancy women. These data have become more alarming when considered that, even though we live in a tropical country, sunlight exposure wasn't sufficient to avoid vitamin D deficiency. Therefore, vitamin $\mathrm{D}$ food sources can be important to these patients. That is why, new studies should be made, considering the mentioned variables. The inclusion of vitamin D blood dosage level in the habitual prenatal care could be an interesting action as rickets prophylaxis in newborns and for preeclampsia. We believe, that though this study was the first step, new aspects should be evaluated and addressed in the near future [27-32]. But now our results show that low blood levels of vitamin $\mathrm{D}$ in the first trimester are associated with pre-eclampsia, but not with birth weight.

\section{References}

[1] Holick MF. Vitamin D deficiency. N Engl J Med. 2007 Jul 19;357(3):266-81. [PMID: 17634462]

[2] Dawodu A, Wagner CL. Prevention of vitamin D deficiency in mothers and infants worldwide - a paradigm shift. Paediatr Int Child Health. 2012 Feb;32(1):3-13. [PMID: 22525442]

[3] Chicote CC, Lorencio FG; Comité de Comunicación de la Sociedad Española de Bioquímica Clínica y Patología Molecular. Vitamina D: una perspectiva actual. Barcelona: Comité de Comunicación de la Sociedad Española de Bioquímica Clínica y Patología Molecular; 2013.

[4] Institute of Medicine (US) Committee to Review Dietary Reference Intakes for Vitamin D and Calcium; Ross AC, Taylor CL, Yaktine AL, Del Valle HB, editors. Dietary Reference Intakes for Calcium and Vitamin D. Washington (DC): National Academies Press (US); 2011. [PMID: 21796828]

[5] Aydogmus S, Kelekci S, Aydogmus H, Eriş S, Desdicioğlu R, Yilmaz B, Sağlam G. High prevalence of vitamin $\mathrm{D}$ deficiency among pregnant women in a Turkish population and impact on perinatal outcomes. J Matern Fetal Neonatal Med. 2015;28(15):1828-32. [PMID: 25260128]

[6] Holick MF. The vitamin D deficiency pandemic: Approaches for diagnosis, treatment and prevention. Rev Endocr Metab Disord. 2017 Jun;18(2):153-65. [PMID: 28516265]

[7] Burris HH, Rifas-Shiman SL, Camargo CA Jr, Litonjua AA, Huh SY, Rich-Edwards JW, Gillman MW. Plasma 25-hydroxyvitamin D during pregnancy and small-for-gestational age in black and white infants. 
Citation: Dias BA, Fraga CAC, de Rezende Goston HSR, Guerra PB, Heringer VCCR, Rodrigues YS, Panconi CR, Coutinho LM, de Souza HD, Batalha SH, Silva CS, Zimmermmann JB. Blood Dosage of Vitamin D in Pregnant Women and Association with Preeclampsia and Fetal Low Weight. Asp Biomed Clin Case Rep. 2020 Feb 21;3(1):51-61.

Original Article

Ann Epidemiol. 2012 Aug;22(8):581-86. [PMID: 22658824]

[8] Urrutia-Pereira M, Solé D. Deficiência de vitamina D na gravidez e o seu impacto sobre o feto, o recémnascido e na infância. Revista Paulista de Pediatria. 2015 Mar 1;33(1):104-13.

[9] Brasil. Sociedade Brasileira de Endocrinologia e Metabologia. Vitamina D novos valores de referência. Accessed on: $01 \quad$ March 2019. https://www.endocrino.org.br/vitamina-d-novosvalores-de-referencia/

[10] Mulligan ML, Felton SK, Riek AE, Bernal-Mizrachi C. Implications of vitamin D deficiency in pregnancy and lactation. Am J Obstet Gynecol. 2010 May;202(5):429.e1-9. [PMID: 19846050]

[11] Tous M, Villalobos M, Iglesias L, FernándezBarrés S, Arija V. Vitamin D status during pregnancy and offspring outcomes: a systematic review and meta-analysis of observational studies. Eur J Clin Nutr. 2020 Jan;74(1):36-53. [PMID: 30683894]

[12] Perreault M, Moore CJ, Fusch G, Teo KK, Atkinson SA. Factors Associated with Serum 25Hydroxyvitamin D Concentration in Two Cohorts of Pregnant Women in Southern Ontario, Canada. Nutrients. 2019 Jan 9;11(1). pii: E123. [PMID: 30634435]

[13] do Prado MR, Oliveira FD, Assis KF, Ribeiro SA, do Prado Junior PP, da Rocha Sant'Ana LF, Priore SE, Franceschini SD. Prevalência de deficiência de vitamina $\mathrm{D}$ e fatores associados em mulheres e seus recém-nascidos no período pós-parto. Revista Paulista de Pediatria. 2015 Sep 1;33(3):286-93.

[14] Baron ED. Selection of sunscreen and sunprotective measures. Accessed on o8 March 2019. https://www.uptodate.com/contents/selection-ofsunscreen-and-sun-protective-

measures/print?search=HEPA\%2oFilters\&selectedTit le $=6 \sim 150$.

[15] Holick MF, Binkley NC, Bischoff-Ferrari HA, Gordon CM, Hanley DA, Heaney RP, Murad MH, Weaver CM; Endocrine Society. Evaluation, treatment, and prevention of vitamin D deficiency: an Endocrine Society clinical practice guideline. J Clin Endocrinol Metab. 2011 Jul;96(7):1911-30. [PMID: 21646368]

[16] Mallet E, Gügi B, Brunelle P, Hénocq A, Basuyau $\mathrm{JP}$, Lemeur $\mathrm{H}$. Vitamin $\mathrm{D}$ supplementation in pregnancy: a controlled trial of two methods. Obstet
Gynecol. 1986 Sep;68(3):300-304. [PMID: 3755517]

[17] Shrimpton R. Global policy and programme guidance on maternal nutrition: what exists, the mechanisms for providing it, and how to improve them? Paediatr Perinat Epidemiol. 2012 Jul;26 Suppl 1:315-25. [PMID: 22742618]

[18] Kaushal M, Magon N. Vitamin D in pregnancy: A metabolic outlook. Indian J Endocrinol Metab. 2013 Jan;17(1):76-82. [PMID: 23776856]

[19] Santos LA, Mamede FV, Clapis MJ, Bernardi JV. Orientação nutricional no pré-natal em serviços públicos de saúde no município de Ribeirão Preto: o discurso e a prática assistencial. Revista LatinoAmericana de Enfermagem. 2006 Oct;14(5):688-94.

[20] Caribé TEG, Lommez TCG, Sena KCL, Barbosa CNS, Teixeira VC, Condé MDS et al. Padrão de consumo de vitamina D e cálcio em gestantes do Vale do Jequitinhonha, Brasil. Revista On line de Acervo Saúde. Accessed on: 1 April 2019.

https://www.acervosaude.com.br/doc/REAS448.pdf [21] Brooke OG, Brown IR, Bone CD, Carter ND, Cleeve HJ, Maxwell JD, Robinson VP, Winder SM. Vitamin D supplements in pregnant Asian women: effects on calcium status and fetal growth. Br Med J. 1980 Mar 15;28o(6216):751-54. [PMID: 6989438]

[22] Vieth R, Chan PC, MacFarlane GD. Efficacy and safety of vitamin D3 intake exceeding the lowest observed adverse effect level. Am J Clin Nutr. 2001 Feb;73(2):288-94. [PMID: 11157326]

[23] Heaney RP, Davies KM, Chen TC, Holick MF, Barger-Lux MJ. Human serum 25hydroxycholecalciferol response to extended oral dosing with cholecalciferol. Am J Clin Nutr. 2003 Jan;77(1):204-10. [PMID: 12499343]

[24] Hutabarat M, Wibowo N, Obermayer-Pietsch B, Huppertz B. Impact of vitamin D and vitamin D receptor on the trophoblast survival capacity in preeclampsia. PLoS One. 2018 Nov 8;13(11):eo2o6725. [PMID: 30408071]

[25] Taufield PA, Ales KL, Resnick LM, Druzin ML, Gertner JM, Laragh JH. Hypocalciuria in preeclampsia. New England Journal of Medicine. 1987 Mar 19;316(12):715-18.

[26] Benachi A, Baptiste A, Taieb J, Tsatsaris V, Guibourdenche J, Senat MV, Haidar H, Jani J, Guizani M, Jouannic JM, Haguet MC. Relationship between vitamin $\mathrm{D}$ status in pregnancy and the risk for 
Citation: Dias BA, Fraga CAC, de Rezende Goston HSR, Guerra PB, Heringer VCCR, Rodrigues YS, Panconi CR, Coutinho LM, de Souza HD, Batalha SH, Silva CS, Zimmermmann JB. Blood Dosage of Vitamin D in Pregnant Women and Association with Preeclampsia and Fetal Low Weight. Asp Biomed Clin Case Rep. 2020 Feb 21;3(1):51-61.

\section{Original Article}

preeclampsia: A nested case-control study. Clinical nutrition. 15 February 2019.

[27] Olivença R, Martins M, Mendes V, Castanheira L. Suplementação de vitamina D na gravidez: qual a evidência?. Revista Portuguesa de Medicina Geral e Familiar. 2016 Aug;32(4):283-85.

[28] Giorelli GV, Matos LN, Saado A, Soibelman VL, Dias CB. No association between 25-hydroxyvitamin D levels and prediabetes in Brazilian patients. A crosssectional study. Sao Paulo Medical Journal. 2015 Apr;133(2):73-77.

[29] Lana ME, Picón DC, Ospino YB. Vitamina D sérica y su relación con adiposidad y resistencia a la insulina en mujeres posmenopáusicas. Acta bioquímica clínica latinoamericana. 2017;51(4):581-92.

[30] Rebouças PC, Netinho JG, Cunrath GS, Ronchi LS, de Melo MM, de Assis Gonçalves Filho F, Muniz RC, Martins AT, de Oliveira RA, Junior RM. Hypovitaminosis D in patients with Crohn's disease. J Coloproctol. 2016 Apr 1;36(2):59-63.

[31] Alves M, Bastos M, Leitão F, Marques G, Ribeiro G, Carrilho F. Vitamina D-importância da avaliação laboratorial. Revista Portuguesa de Endocrinologia, Diabetes e Metabolismo. 2013 Jan 1;8(1):32-39.

[32] Catarino AM, Claro C, Viana I. Vitamina D Perspectivas. Revista SPDV. 2016;74(4):345-53. 